\title{
The Modern Sample of Integrative Teaching in Chemistry Lessons
}

\author{
Ravan Mammadov \\ Bilasuvar Lyceum-School Complex named after the National Hero, The Republic of Azerbaijan
}

Copyright (C) 2015 by authors, all rights reserved. Authors agree that this article remains permanently open access under the terms of the Creative Commons Attribution License 4.0 International License

\begin{abstract}
The following article deals with the useful, new, creative forms of integrative teaching of Chemistry in secondary schools and Lyceums creating connections between Chemistry and other school subjects. The samples from work experience are given in this article.
\end{abstract}

Keywords Dissociation, Ions, Electroconductivity, Cellule, Solution

\section{Introduction}

International education practice shows that to create links of integration between different subjects is the most important factor in the lesson which develops the quality of teaching. If these relationships are strong, students can comprehend the chemical process and conception comprehensively. Refering to "Bluestein J. Cherry C. 2003. Skills for Successful Teaching.USA: Brighter Child Press on page 84-91" the knowledge and skills about nature is formed completly in the stududents' brains due to integrative teaching. Therefore I always try integrative teaching in the chemistry lesson, especially I pay attention to knowledge of biology, physics and math that have connection with chemistry conceptions. In my practice I've become convinced that integrative teaching helps the student to get universal education. I would like to present the sample of integrative teaching lesson plan about my practice.

\section{Problem Statement}

The topic of electrolytic dissociation of integrative teaching in chemistry lesson.

\section{Purpose of the Study}

1)Students must be able to compare electrolytes and nonelectrolytes systematicly

2)Students must be able to explain the essence of the electrolytic dissociation

3)Students must be able to create connection between dissociation and hydratisations

4)Students must be able to create connection between the facts connected with the conceptions of different subjects (chemistry, biology, physics and math) when they research electrolytic dissociation.

\section{Methods}

To create situation with problem, brain storming, discussion, cluster, experimental methods related chemical experiment.

\section{Resources}

Instrument for controlling electroconductivity of solution, dry $\mathrm{NaCl}, \mathrm{NH}_{4} \mathrm{NO}_{3}, \mathrm{H}_{2} \mathrm{SO}_{4}, \mathrm{CuSO}_{4}$, sugar, glucose, distilled water, alive frog, blood plasma, the presentation Power Point.

\section{Activities Done in the Process of the Research}

Teacher must pay attention the students' skills at the beginning of the lesson in order to stimulate the interest of the students. I had given a task to the students connected with the subject of electrolytic dissociation before teaching this topic. At the same time the students repeated the topics of the structure of atom, solutions, chemical bond, crystals, electroconductivity of materials and chemical composition of cellule.Refering to Rustamov F.A. 2010. Pedagogy. Baku: Science and Education Press on page 128 these tasks to create foundation or to pave the way for the students to comprehend new subject of lesson.

Electroconductivity of different pure substances and 
solutions is checked by students with a special instrument. Then strong $\mathrm{H}_{2} \mathrm{SO}_{4}$ and $\mathrm{NH}_{4} \mathrm{NO}_{3}$ is dissolved in water and at the same time the facts of becoming warmer and colder in the prosess of solvation, dry $\mathrm{CuSO}_{4}$ also is dissolved in water and is observed the change of colour - these reactions cause great interest in class and stimulate the interest of students. Then students subject the frog to weak electric current and then observe the reflex of frog. The electroconductivity of blood plasma is checked by sudents at last. After that I show an animation to the students about electrolytic dissociation.

I note all students, ideas and hypothesis on the blackboard witch are connected with the essence of these reactions. After the motivation of students I ask the pupils questions for research:

What is the essence of the electrolytic dissociation?

I divide all the pupils into three groups and give them different tasks after putting the question for research. Refering to "Hassard J.2012.The Art of Teaching Science.London:Oxford University Press on page 104-107" when the groups solve these tasks they need to apply necessary knowledge and skills not only infomation on chemistry, but also on biology, physics and math together.When I define the amount of appropriate methods refering to "Bain K.2004. What the Best College Teachers Do. Cambridge, MA: Harvard University Press on page 92-98" and "Mehrabov A. 2006. Pedagogical technology, Baku: Mutercim Press on page 156-164." Pupils research in four directions as following table.

Table 1. Directions of research

\begin{tabular}{|c|c|c|c|c|}
\hline \multirow{2}{*}{ Topic } & \multicolumn{4}{|c|}{ Subject } \\
\cline { 2 - 5 } & Chemistry & Biology & Physics & Math \\
\hline $\begin{array}{c}\text { Electrolytic } \\
\text { dissociation }\end{array}$ & $\begin{array}{c}\text { Chemical } \\
\text { properties } \\
\text { of } \\
\text { electrolytes }\end{array}$ & $\begin{array}{c}\text { Ions of } \\
\text { cytoplasme } \\
\text { of cellule }\end{array}$ & $\begin{array}{c}\text { Coulomb's } \\
\text { forces in } \\
\text { sollution of } \\
\text { electrolytes }\end{array}$ & $\begin{array}{c}\text { mathemati } \\
\text { cal analysis } \\
\text { of research }\end{array}$ \\
\hline $\begin{array}{c}\text { Amount of } \\
\text { appropriate } \\
\text { methods }\end{array}$ & 4 & 2 & 3 & 3 \\
\hline
\end{tabular}

Each group's task is as following:

\section{Group}

1. Why the solution of $\mathrm{NaCl}$ has electroconductivity, but sugar solution doesn't?

2. What sort of chemical bonds are possible for electrolytes?

3. Describe the chemical equation of electrolytic dissociation for $\mathrm{NaCl}$.

\section{Group}

1. Explain the following notion:
a) Cation
b) anion
c) cathode
d) anode

2. What is the role of relative permittivity $(\varepsilon)$ of water between $\mathrm{Na}+$ and $\mathrm{Cl}$ - in solution? Give explanation of Coulomb's Law in this situation.

3. There are three solutions in following flasks:
a) in the first flask: 4 moles of $\mathrm{K}_{2} \mathrm{SO}_{4}$
b) in the second flask: 12 moles of $\mathrm{NaCl}$
c) in the third flask: 9 moles of $\mathrm{Al}\left(\mathrm{NO}_{3}\right)_{3}$

Complete electrolytic dissociation of salt take place in each flask. Prove that in the direction of $a \rightarrow b \rightarrow c$ amount of ions of salt to form arithmetic progression.

\section{Group}

1. Explain existence of ions in cytoplasme of cellule of biological creatures.

2. What is the reason of becoming warmer when strong $\mathrm{H}_{2} \mathrm{SO}_{4}$ is solved in water, but why we observe becoming colder when $\mathrm{NH}_{4} \mathrm{NO}_{3}$ is solved in water?

3. Why colour change is observed when dry $\mathrm{CuSO}_{4}$ is solved in water?

For research is given limited definite time to the groups. I facilitate to the students as a scientific guide during this time.The pupils analyse directions of research: chemical properties of electrolytes, Ions of cytoplasme of cellule, Coulomb's forces in sollution of electrolytes and mathematical analysis of research. Consequently, students discover essence of the things about chemistry themselves.

\section{Findings}

When research is over the groups start to exchange their conclusions. Each group prepare the presentation on the computer. Leader of each group presents to all the students about own group,s research on the activeboard. In the process of the integrative teaching I defined new pedagogical advances which ensure more effective integration between different subjects, skills in pupils, brains.

Referring to "Susan J.2010. A conceptual, İntegrated Approach to Teaching Science. USA: Library of Congress Publication Press on page 92-96" the integrative teaching methods show that the pupils gain very useful superiority in the lesson in comparison with other methods. 
Table 2. Comparison of the results of integrative teaching and other teaching methods

\begin{tabular}{|c|c|c|}
\hline № & İntegrative teaching & The other teaching \\
\hline 1 & $\begin{array}{l}\text { Increases pupils' abilities to analyze and easily understand } \\
\text { cause-result relations between the different physic-chemical and } \\
\text { biological processes, using the knowledge gained in different } \\
\text { subjects. }\end{array}$ & $\begin{array}{l}\text { The cause-result relations are very poor and the pupils mainly pay } \\
\text { attention to the facts and try to remember the results of the stages. } \\
\text { Referring to "Ahmadov H.H.2008. Pedagogy. Baku: Education Press on } \\
\text { page 142" they cannot create relationships between the separate } \\
\text { chemical processes. }\end{array}$ \\
\hline 2 & $\begin{array}{c}\text { My researches show that sufficiency is very high and I can save } \\
\text { a lot of time (about } 90 \% \text { ) in teaching the topic) }\end{array}$ & $\begin{array}{l}\text { Referring to "Norbert J.Melanie M.Thomas J.2005.Chemists, Guide to } \\
\text { Effective Teaching. USA: Prentice Hall on page } 88-90 \text { " sufficiency is } \\
\text { low and quality of perceiving the topic is much lower than in integrative } \\
\text { teaching. }\end{array}$ \\
\hline 3 & $\begin{array}{l}\text { The pupils tend to solve the problems by themselves and about } \\
80 \% \text { of the problems are solved independently, thus their } \\
\text { inclination for creativity is extended. }\end{array}$ & $\begin{array}{l}\text { In comparison with the integrative teaching students solve only about } \\
\qquad 30 \% \text { of the problems. }\end{array}$ \\
\hline
\end{tabular}

\section{Discussion}

The pupils start to discuss the information they gained from their research. In this time I am very attentive, I pay special attention to the integration between different subjects (chemistry, biology, physics and math). For example, I ask the pupils then following questions in order to create integration.In this time I refering to Susan J.2010. A conceptual, İntegrated Approach to Teaching Science. USA: Library of Congress - Press, McFadden.1997. Science Plus Technology and society-- level red, USA::Holt Press, Eilks İ. Hofstein A.2013.Teaching Chemistry.Rotterdam: Sense Publisher Press, Kumar S. 2004. Methods of Teaching Chemistry, New Delhi: Discovery House Press,Bluestein J. Cherry C. 2003. Skills for Successful Teaching.USA: Brighter Child Press, Bain K.2004. What the Best College Teachers Do. Cambridge, MA: Harvard University Press, Aliyev A.2008 .Chemistry Curiculum Conseption.Baku: Education Press, Conover W.2010.Innovative Methods of Teacing and Learning Chemistry.USA-ACS publications, Frazee.B. 2000 .Integrated Teaching Methods. Delmar Publishers-Press, Barke.H.D.2012.Essentials of Chemical Education.Berlin:Heidelberg Press and Jones M. Jones. G. Acaster D. 1997.Chemistry. London: Cambridge university Press.

1. What sort of chemical bonds are possible for electrolytes and nonelectrolytes?

2. What similarities and differences are there between electrolytes and other conductors?

3. What is the reason of electroconductivity of cytoplasme of cellule?

4. Why Coulomb's forces weaken between the ions when electrolyte is solved in water?

5. What ions is exist in the cytoplasme of cellule?

6. What is the reason of electrolytic dissociation of salt in water?

7. What is the relative permittivity?

8. What is the role of relative permittivity $(\varepsilon)$ of water between $\mathrm{Cu}^{2+}$ and $\mathrm{SO}_{4}{ }^{2-}$ in solution?

9. Why the solution of $\mathrm{CuSO}_{4}$ has electroconductivity, but glucose solution doesn't?

10. Why becoming warmer when strong $\mathrm{H}_{2} \mathrm{SO}_{4}$ is solved in water?

11. What sort of chemical bonds are there between ions and molecule of water in solution?

12. Explain the connection between dissociation and hydratisations

13. What differences are there between cation and anion or cathode and anode?

14. Give explanation of Coulomb's Law comparative form between ions in dry salt and solution of salt in water.

15. Why becoming colder when $\mathrm{NH}_{4} \mathrm{NO}_{3}$ is solved in water?

16. What do you know mathematical analysis of amount of ions after electrolytic dissociation?

17. What differences are there between chemical properties of electrolytes and nonelectrolytes ?

18. Explain existence of ions in cytoplasme of cellule of frog.

19. Are there ions in cytoplasme of cellule of human?

20. Describe the chemical equation of electrolytic dissociation for $\mathrm{H}_{2} \mathrm{SO}_{4}$

21. What differences electroconductivity of $\mathrm{NaCl}$, $\mathrm{CH}_{3} \mathrm{COOH}$ and sugar solution?

22. Give explanation is surrounded the ions by the water molecule in hydratisations process.

23. Why the salt has electroconductivity, when dry $\mathrm{NaCl}$ is melt?

24. Form the principal theses of electrolytic dissociation.

25. What significance of electrolytic dissociation for realizing other chemical process?

26. Why colour change is observed when dry $\mathrm{CuSO}_{4}$ is solved in water?

27. What is the reason existence of ions in cytoplasme of cellule of biological creatures.

28. What sort of chemical bonds are possible for nonelectrolytes?

29. Why the solution of $\mathrm{HNO}_{3}$ has electroconductivity, but sugar solution doesn't?

30. Attention following details, realizing and compare them:

a) Chemical properties of electrolytes, the dissociation of matter in water and the hydratisations of ions in water

b) Ions of cytoplasme of cellule and the cause of existence 
of ions in cytoplasme of cellule

c) Coulomb's forces in sollution of electrolytes, the cause of Coulomb's forces weaken between the ions when electrolyte is solved in water and the cause of electroconductivity of solution.

d) Mathematical analysis of research and mathematical analysis of result which is gained in research.

31. Why colour change is observed when dry $\mathrm{CuSO}_{4}$ is solved in water?

32. What sort of chemical bonds are possible for electrolytes?

33. Describe the chemical equation of electrolytic dissociation for $\mathrm{Ca}(\mathrm{OH})_{2}$

34. What is the role of relative permittivity $(\varepsilon)$ of water between $\mathrm{K}^{+}$and $\mathrm{Cl}^{-}$in solution? Give explanation of Coulomb's Law in this situation.

35. There are three solutions in following flasks:

a) in the first flask: 2 moles of $\mathrm{Na}_{2} \mathrm{SO}_{4}$

b) in the second flask: 6 moles of $\mathrm{KCl}$

c) in the third flask: 4,5 moles of $\mathrm{Fe}\left(\mathrm{NO}_{3}\right)_{3}$

Complete electrolytic dissociation of salt take place in each flask. Prove that in the direction of $a \rightarrow b \rightarrow c$ amount of ions of salt to form arithmetic progression

\section{Conclusions}

After discussion the generalization is conducted by the pupils, if my help is required I assist my students. I try to create connection with actual life and practice by the use of integrative teaching method. Pupils construct following integrative scheme as a result and they refering to "McFadden.1997. Science Plus Technology and society-level red, USA::Holt Press on page 108-140" and "Norman.H. Cunningham J. 1999 .Chemistry Activities. California: Northridge Press on page 56-64" too.

Refering to "Jones M. Jones. G. Acaster D. 1997.Chemistry. London: Cambridge university Press on page 151-158" pupils can solve the sample tasks when they apply their skills into practice in creative form. Refering to "Taber K.2012. Teaching secondary chemistry,London: Hodder Education on page 74-78", "Kumar S. 2004. Methods of Teaching Chemistry, New Delhi: Discovery House Press on page 88-94", "Kumar S. 2004. Methods of Teaching Chemistry, New Delhi: Discovery House Press on page 72-79" and "İlyasov M.2013.Teacher,s Pedagogical Skills . Baku: Science and Education Press". I make evaluation of the students' activities with the following criteria at the end of the lesson.

Table 3. The results of the different directions of research

\begin{tabular}{|c|c|c|c|c|}
\hline \multirow{2}{*}{ Topic } & \multicolumn{4}{|c|}{ Subject } \\
\hline & Chemistry & Biology & Physics & Math \\
\hline Electrolytic dissociation & $\begin{array}{c}\text { Chemical properties of } \\
\text { electrolytes }\end{array}$ & $\begin{array}{c}\text { Ions of cytoplasme of } \\
\text { cellule }\end{array}$ & $\begin{array}{l}\text { Coulomb's forces in } \\
\text { sollution of electrolytes }\end{array}$ & $\begin{array}{c}\text { mathematical analysis of } \\
\text { research }\end{array}$ \\
\hline $\begin{array}{c}\text { Details of process that the } \\
\text { pupils have perceive }\end{array}$ & $\begin{array}{l}\text { The dissociation of matter } \\
\text { in water } \\
\text { The hydratisations of ions } \\
\text { in water }\end{array}$ & $\begin{array}{l}\text { The cause of existence } \\
\text { of ions in cytoplasme of } \\
\text { cellule }\end{array}$ & $\begin{array}{l}\text { The cause of Coulomb's } \\
\text { forces weaken between the } \\
\text { ions when electrolyte is } \\
\text { solved in water } \\
\text { The cause of } \\
\text { electroconductivity of } \\
\text { solution }\end{array}$ & $\begin{array}{l}\text { mathematical analysis of } \\
\text { result which is gained in } \\
\text { research }\end{array}$ \\
\hline
\end{tabular}

Table 4. The criteria of evaluation of the students, skills in integrative teaching.

\begin{tabular}{|c|c|c|c|}
\hline Criteria & I group & II group & III group \\
\hline \multicolumn{4}{|l|}{ Can explain essence of electrolytic dissociation } \\
\hline \multicolumn{4}{|l|}{ Can solve the task } \\
\hline \multicolumn{4}{|l|}{ Can present the result of the research } \\
\hline \multicolumn{4}{|l|}{ Can conduct the experiment freely } \\
\hline Is disciplined and can work in cooperation & & & \\
\hline
\end{tabular}


I use selfevaluation and reflexion for the students at the end of the lesson too, refering to Aliyev A.2008 .Chemistry Curiculum Conseption.Baku: Education Press, Conover W.2010.Innovative Methods of Teacing and Learning Chemistry.USA-ACS publications, Frazee.B. 2000 .Integrated Teaching Methods. Delmar Publishers-Press and Barke.H.D.2012.Essentials of Chemical Education.Berlin:Heidelberg Press Increases pupils' abilities to analyze and easily understand cause-result relations between the different physic-chemical and biological processes, using the knowledge gained in different subjects. My researches show that sufficiency is very high and I can save a lot of time (about $90 \%$ ) in teaching the topic).The pupils tend to solve the problems by themselves and about $80 \%$ of the problems are solved independently, thus their inclination for creativity is extended. In the integrative teaching process pupils are master of skills, what necessary for their life: 1) Students can compare electrolytes and nonelectrolytes systematicly 2) Students can explain the essence of the electrolytic dissociation 3) Students can create connection between dissociation and hydratisations 4) Students can create connection between the facts connected with the conceptions of different subjects (chemistry, biology, physics and math) when they research electrolytic dissociation. 5) The selfevaluation skills are progress in pupil,s brain. 6) Teacher can create connection with actual life and practice by the use of integrative teaching method very easily. 7) Students can solve the task very easily. 8) Students can explain essence of chemical process deeply. 9) Students can present the result of the research perfectly. 10) Student can conduct the experiment freely. 11) Students are disciplined and can work in cooperation. Consequently, the integrative teaching helps the students as perfectly to perceive the laws of nature.

\section{REFERENCES}

[1] Rustamov F.A. 2010. Pedagogy. Baku: Science and Education Press
[2] Jones M. Jones. G. Acaster D. 1997.Chemistry. London: Cambridge university Press

[3] McFadden.1997. Science Plus Technology and society-- level red, USA::Holt Press

[4] Bluestein J. Cherry C. 2003. Skills for Successful Teaching.USA: Brighter Child Press

[5] Bain K.2004. What the Best College Teachers Do. Cambridge, MA: Harvard University Press

[6] Eilks İ. Hofstein A.2013.Teaching Chemistry.Rotterdam: Sense Publisher Press

[7] Ahmadov H.H.2008. Pedagogy. Baku: Education Press

[8] İlyasov M.2013.Teacher,s Pedagogical Skills . Baku: Science and Education Press

[9] Mehrabov A. 2006. Pedagogical technology, Baku: Mutercim Press

[10] İbrahimov F. 2013. Pedagogy. Baku: Mutercim Press

[11] Kumar S. 2004. Methods of Teaching Chemistry, New Delhi: Discovery House Press

[12] Taber K.2012. Teaching secondary chemistry,London: Hodder Education

[13] Hassard J.2012.The Art of Teaching Science.London:Oxford University Press

[14] Norman.H. Cunningham J. 1999 .Chemistry Activities. California: Northridge Press

[15] Norbert J.Melanie M.Thomas J.2005.Chemists, Guide to Effective Teaching. USA: Prentice Hall

[16] Susan J.2010. A conceptual, İntegrated Approach to Teaching Science. USA: Library of Congress - Press

[17] Aliyev A.2008 .Chemistry Curiculum Conseption.Baku: Education Press

[18] Conover W.2010.Innovative Methods of Teacing and Learning Chemistry.USA-ACS publications

[19] Frazee.B. 2000 .Integrated Teaching Methods. Delmar Publishers-Press

[20] Barke.H.D.2012. Essentials of Chemical Education.Berlin:Heidelberg Press 